\title{
Accessibility Model in Electronic Government: Evaluation of Brazilian Web Portals
}

\author{
Alberto Dumont Alves Oliveira \\ School of Arts, Sciences and \\ Humanities - University of São Paulo \\ Av. Arlindo Bettio, 1000 \\ São Paulo, SP - Brazil \\ albertodumont@usp.br
}

\author{
Eliane Moreira de Souza \\ School of Management and Business \\ Federal University of Uberlândia \\ Av. João Naves de Ávila, 2121 \\ Uberlândia, MG - Brazil \\ eliane.moreira@ufu.br
}

\author{
Marcelo Medeiros Eler \\ School of Arts, Sciences and \\ Humanities - University of São Paulo \\ Av. Arlindo Bettio, 1000 \\ São Paulo, SP - Brazil \\ marceloeler@usp.br
}

\begin{abstract}
The Brazilian federal government has promoted several actions towards addressing digital accessibility in e-government systems once it is essential for all citizens to take part on participatory digital governance and have access to important information and online services. In this paper, we evaluate the main web portals of 28 federal agencies with ministry status to check whether they comply with the main laws and standards related to digital accessibility, namely the Accessibility Model in Electronic Government, also known in Portuguese as e-MAG; the Digital Government Identity; and the Accessibility Circumstantial Report. Unfortunately, most federal agencies fail to deliver acceptable levels of accessibility and to present a digital accessibility assessment along with a work plan to address the known issues. We also present an interview with a blind citizen to understand the Brazilian digital accessibility scenario from the perspective of a person with disability. The results of the interview confirmed that, even with the existence of e-MAG, the Brazilian federal government has yet a long way to walk to assure citizens the basic rights to access information, online services and take part in important decisions.
\end{abstract}

\section{CCS Concepts}

- Human-centered computing $\rightarrow$ Accessibility theory, concepts and paradigms $\bullet$ Human-centered computing $\rightarrow$ Empirical studies in accessibility - Human-centered computing $\rightarrow$ Accessibility systems and tools - Applied computing $\rightarrow$ E-government $\quad$ Information systems $\rightarrow$ World Wide Web •Information systems $\rightarrow$ Hypertext languages.

\section{Keywords}

Electronic government; e-government; digital governance; accessibility; e-MAG, Brazil.

\section{INTRODUCTION}

Electronic Government has been defined as the strategic use of information and communication technologies (ICT) to increase interactivity and participation in the government-society relationship [18]. The correct use of information systems in a government brings many benefits such as greater transparency, access to information and online services, agility in processes,

Permission to make digital or hard copies of all or part of this work for personal or classroom use is granted without fee provided that copies are not made or distributed for profit or commercial advantage and that copies bear this notice and the full citation on the first page. To copy otherwise, or republish, to post on servers or to redistribute to lists, requires prior specific permission and/or a fee.

SBSI 2017, June $5^{\text {th }}-8^{\text {th }}, 2017$, Lavras, Minas Gerais, Brazil.

Copyright SBC 2017. strengthening of democracy and a more participatory society [5][25][26].

Recently, the Brazilian Federal Government has defined the goal of expanding the use of ICT into an open and self-service platform, in which citizens can have a more effective participation in government decisions, access to services from computers and cell phones, and oversight public budget and expenses through transparency and use of open government data [5]. To achieve such a goal, it is critical that digital platforms are accessible for any citizen.

Digital accessibility represents, for any user, not only the right to access information, but also the right to eliminate barriers which may compromise their reading, browsing and usage of digital services regardless of the available format [4]. Although digital accessibility impacts everyone, people with disability deserves more attention. If accessibility barriers are not addressed, electronic government solutions can exclude many citizens from accessing important information and being part of significant decisions [1]. In fact, there are approximately 45 million people with disability (visual, auditory, motor, mental or intellectual) in Brazil according to the 2010 IBGE Demographic Census [10][13][21].

Since 2004, the Brazilian federal government has promoted actions towards addressing digital accessibility in e-government systems, which include the creation of booklets, legislation and the Accessibility Model in Electronic Government (e-MAG, in Portuguese), an accessibility standard based on the International Web Content Accessibility Guidelines (WCAG) that must be used by all federal institutions [7][8]. Since 2015, federal institutions must publish an accessibility circumstantial report to show a work plan to implement accessibility requirements defined by the federal government. In addition, web portals must use the e-MAG and the Digital Government Identity (IDG, in Portuguese), a standard portal that promotes the implementation of web standards and basics accessibility functionality.

Despite these investments, a research conducted by the Brazilian Federal Audit Court (TCU, in Portuguese), in 2014, revealed that few federal institutions comply with e-government standards such as e-MAG [23]. In 2015, an investigation used the daSilva accessibility evaluator to analyses the web portals of the 38 Brazilian ministries of that period and confirmed that most web portals fail to implement several guidelines proposed in the eMAG model [16]. In another survey, TCU revealed that federal organizations have problems to hire and keep enough IT staff to cope with the high demand in this area, which jeopardizes the correct use of many e-government standards [24]. 
Since the publication of these studies, there have been considerable changes in the Brazilian political scenario. The number of ministries has been reduced to 24 , new tools such as ASESWeb evaluator was emerged and new legislation that involve digital accessibility have been published, for example, Law No 13.146, also known as statute of the person with disabilities, which requires the publication of detailed accessibility reports; and Ordinance No 1, which specifies what it should contain in the accessibility work plan and in these reports [13][14][17].

The main goal of this paper is to investigate whether there has been any change in the federal government web portals scenario with respect to their compliance with accessibility standards and legislation. We evaluated the main web portal of the 28 federal agencies with ministry status to check whether they: i) implement the IDG; ii) publish the Accessibility Circumstantial Report; iii) comply with the e-MAG standard; and iv) were implemented using the tools recommended by the federal government. We defined the level of compliance of the web portals with the eMAG using ASESWeb, a tool launched by the federal government in 2016 that evaluate web portals accessibility based on the e-MAG.

Furthermore, we present an interview conducted with a disabled person to complement our analysis on the Brazilian digital accessibility scenario. This interview aims to show how are the web navigation in the perception of who needs more digital accessibility and portals with fully adherence to the e-MAG.

Our results show that, although accessibility concerns have increased in the last years, most analyzed federal web portals still does not comply with current federal legislation in several aspects: around $90 \%$ of the web portals do not published the accessibility circumstantial report; only 3\% of the web portals have a greater than $95 \%$ compliance with e-MAG; $10 \%$ of the web portals still does not implement the IDG; and $7.2 \%$ of the web portals were not implemented by Content Management Systems as recommended by the federal government.

The remainder of this paper is organized as follows. Section 2 provides background on digital accessibility in Brazil. Section 3 presents an analysis of federal government web portals. Section 4 describes the results of the interview with a disabled person. Section 5 provides some discussion on results. Section 6 shows related work. Finally, Section 7 presents the concluding remarks and future directions.

\section{DIGITAL ACCESSIBILITY IN BRAZIL}

The Brazilian Digital Government was first introduced in 2000. Since then, it has been widely used to straighten the relationship with citizens and to provide online services and transparent access to information [15][18][19]. The Brazilian Digital Government is evolving and, slowly, it has been reaching better positions in the ranking of the e-government survey conducted by the United Nations. Brazil is in the Upper Middle Income category, and currently occupies the 51st position in the e-government ranking and the 37 th in the e-Participation ranking [15][25][26]. To provide citizens with better services and participatory digital governance, accessibility is a key factor [25]

\subsection{Accessibility legislation}

Since 2000, the Brazilian government has published several laws concerning accessibility, as shown in Table 1. Complying with legislation, standards and rules created by the Brazilian Digital Government is mandatory for all instances of the Information Technology Resources Administration System (SISP, in Portuguese), an organization which includes all federal agencies [8].

Table 1. Legislation involving accessibility [7][8].

\begin{tabular}{|l|c|l|}
\hline \multicolumn{1}{|c|}{ Official Order } & \multicolumn{1}{c|}{ Date } & \multicolumn{1}{c|}{ Highlight } \\
\hline Law No. 10.048 & $08 / 11 / 2000$ & $\begin{array}{l}\text { Priority of service to the people } \\
\text { it specifies }\end{array}$ \\
\hline Law No. 10.098 & $19 / 11 / 2000$ & Accessibility promotion \\
\hline Decree No. 5.296 & $02 / 12 / 2004$ & $\begin{array}{l}\text { Regulates Law No. 10.048 and } \\
\text { Law No. 10.098 }\end{array}$ \\
\hline Ordinance No. 3 & $07 / 07 / 2007$ & $\begin{array}{l}\text { Establish e-MAG in the federal } \\
\text { government }\end{array}$ \\
\hline Decree No. 6.949 & $25 / 08 / 2009$ & $\begin{array}{l}\text { Rights of person with } \\
\text { disabilities }\end{array}$ \\
\hline Law No. 12.527 & $12 / 11 / 2011$ & $\begin{array}{l}\text { Transparency and access to } \\
\text { information }\end{array}$ \\
\hline Decree No. 7.724 & $16 / 05 / 2012$ & Regulates Law No. 12.527 \\
\hline $\begin{array}{l}\text { Normative } \\
\text { Instruction No. } 8\end{array}$ & $19 / 12 / 2014$ & $\begin{array}{l}\text { Establishes the Digital } \\
\text { Government Identity (IDG) }\end{array}$ \\
\hline Law No. 13.146 & $06 / 07 / 2015$ & $\begin{array}{l}\text { Inclusion of the person with } \\
\text { disabilities }\end{array}$ \\
\hline Ordinance No. 1 & $12 / 01 / 2017$ & $\begin{array}{l}\text { Circumstantial report and } \\
\text { accessibility work plan }\end{array}$ \\
\hline
\end{tabular}

We highlight the Ordinance No. 3 that established the Accessibility Model in Electronic Government (e-MAG, in Portuguese), which is an accessibility model for public administration web portals; and Normative Instruction No. 8, that established the Digital Government Identity (IDG, in Portuguese), which standardizes the digital visual identity and the navigation logic of the government web portals [7][8].

The most recent action is Ordinance No. 1, of 2017, which regulates how the Circumstantial Report of Accessibility must be written. The Circumstantial Report of Accessibility has two components: the Digital Accessibility Electronic Form (FAD, in Portuguese), in which every public institution must answer a web form with questions related to accessibility and publish the result; and the Work Plan for Accessibility, document that should include the steps and the schedule for the institution to adjust, in six months, accessibility lacks in a particular virtual environment. This report must be signed by the IT manager, submitted to Federal Public Prosecutor's Office (PFDC, in Portuguese) of the Federal Public Ministry (MPF, in Portuguese), and published on every federal institution's web portal [7][13].

\subsection{Digital Government Identity}

The Digital Government Identity, also known in Portuguese as IDG, standardizes federal agencies web portals to facilitate citizens access to the information and services [20]. Figure 1 shows the IDG model applied in a federal government web portal. It decreases the development time since there is no need to design and implement a different visual project for each web portal. Moreover, it guarantees a uniform navigation through the various web portals of the Brazilian government, regardless of the device being used, and promotes the implementation of the best practices regarding web standards and basics accessibility functionality such as universal links to go straight to certain parts of the screen, high contrast feature and accessibility area [8][20]. 
XIII Brazilian Symposium on Information Systems, Lavras, Minas Gerais, June 5-8, 2017

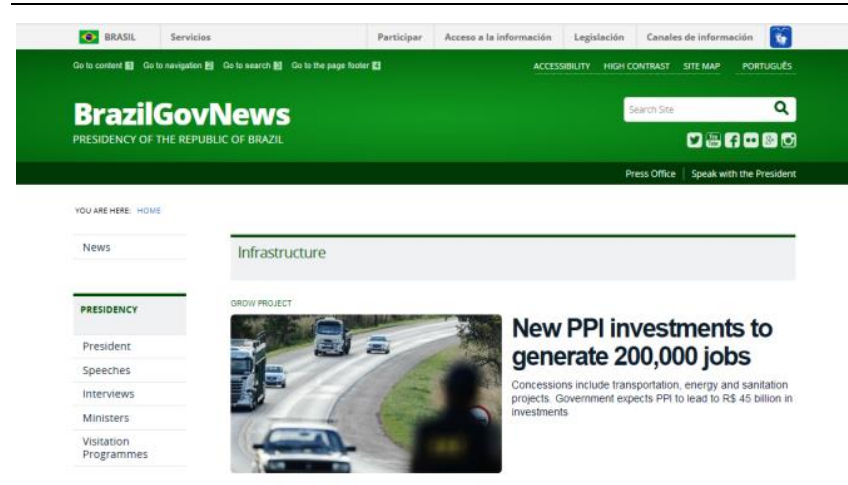

Figure 1. Digital Government Identity.

\section{3 e-MAG: Accessibility Model in Electronic Government}

The e-MAG is a specialized version of the International Web Content Accessibility Guidelines (WCAG), which is a standard proposed by the World Wide Web Consortium (W3C) and is part of the Web Accessibility Initiative (WAI) [12][27]. E-MAG is committed to be the guiding force in the development and adaptation of federal government digital content, ensuring access to information for all stakeholders, regardless of their physical, motor, perceptual, cultural and social capacities [7]. It has fortyfive accessibility recommendations split in six sections, as shown in Table 2.

Table 2. e-MAG recommendations per Sections [7].

\begin{tabular}{|c|c|c|}
\hline Section & \multicolumn{2}{|c|}{ Recommendations } \\
\hline \multirow{5}{*}{ Marking } & Web Standards (W3C) & $\begin{array}{l}\text { Do not use tables for } \\
\text { diagramming }\end{array}$ \\
\hline & HTML Organization & Separete Adjacent links \\
\hline & Header levels & Divide information areas \\
\hline & Reading and tabulation & Opening of new instances \\
\hline & Anchors to content & --- \\
\hline \multirow{4}{*}{$\begin{array}{l}\text { Behavior } \\
\text { (DOM) }\end{array}$} & $\begin{array}{l}\text { All page functions via } \\
\text { keyboard }\end{array}$ & $\begin{array}{l}\text { Provide alternative to } \\
\text { modify time limit }\end{array}$ \\
\hline & $\begin{array}{l}\text { Programmable objects } \\
\text { are accessible }\end{array}$ & $\begin{array}{l}\text { Do not use intermittent } \\
\text { screen }\end{array}$ \\
\hline & $\begin{array}{l}\text { Do not use pages with } \\
\text { periodic auto-update }\end{array}$ & $\begin{array}{l}\text { User control over } \\
\text { temporal changes }\end{array}$ \\
\hline & $\begin{array}{l}\text { Do not use automatic } \\
\text { page redirection }\end{array}$ & --- \\
\hline \multirow{6}{*}{$\begin{array}{l}\text { Content / } \\
\text { Information }\end{array}$} & $\begin{array}{l}\text { Identify the main } \\
\text { language of the page }\end{array}$ & $\begin{array}{l}\text { Use accessible image } \\
\text { maps }\end{array}$ \\
\hline & $\begin{array}{l}\text { Report language change } \\
\text { in content }\end{array}$ & $\begin{array}{l}\text { Provide documents in } \\
\text { accessible formats }\end{array}$ \\
\hline & $\begin{array}{l}\text { Provide a informative } \\
\text { title to the page }\end{array}$ & $\begin{array}{l}\text { In tables, use titles and } \\
\text { summaries appropriately }\end{array}$ \\
\hline & $\begin{array}{l}\text { Tell the user about your } \\
\text { location on the page }\end{array}$ & $\begin{array}{l}\text { Associate data cells with } \\
\text { header cells }\end{array}$ \\
\hline & $\begin{array}{l}\text { Describe links clearly } \\
\text { and succinctly }\end{array}$ & $\begin{array}{l}\text { Ensure reading and } \\
\text { understanding of content }\end{array}$ \\
\hline & $\begin{array}{l}\text { Provide text alternative } \\
\text { for images }\end{array}$ & $\begin{array}{l}\text { Provide an explanation for } \\
\text { abbreviations }\end{array}$ \\
\hline \multirow{2}{*}{$\begin{array}{l}\text { Presentation } \\
\text { / Design }\end{array}$} & $\begin{array}{l}\text { Foreground and } \\
\text { background Contrast }\end{array}$ & $\begin{array}{l}\text { Allow resize without loss } \\
\text { of functionality }\end{array}$ \\
\hline & $\begin{array}{l}\text { Do not use only color to } \\
\text { differentiate elements }\end{array}$ & $\begin{array}{l}\text { Enable the focus element } \\
\text { to be visually evident }\end{array}$ \\
\hline
\end{tabular}

\begin{tabular}{|c|l|l|}
\hline \multirow{5}{*}{ Section } & \multicolumn{2}{|c|}{ Recommendations } \\
\hline \multirow{4}{*}{ Multimedia } & $\begin{array}{l}\text { Provide alternative to } \\
\text { video }\end{array}$ & $\begin{array}{l}\text { Provide audio control for } \\
\text { sound }\end{array}$ \\
\cline { 2 - 3 } & $\begin{array}{l}\text { Provide alternative to } \\
\text { audio }\end{array}$ & Provide animation control \\
\cline { 2 - 3 } & $\begin{array}{l}\text { Offer audiodescription } \\
\text { for prerecorded video }\end{array}$ & --- \\
\hline \multirow{5}{*}{ Forms } & $\begin{array}{l}\text { Provide text alternatives } \\
\text { to form image buttons }\end{array}$ & $\begin{array}{l}\text { Provide instructions for } \\
\text { data entry }\end{array}$ \\
\cline { 2 - 3 } & \begin{tabular}{l} 
Link labels to your fields \\
\cline { 2 - 3 }
\end{tabular} & $\begin{array}{l}\text { Feedback for data entry } \\
\text { errors and confirm }\end{array}$ \\
\cline { 2 - 3 } & $\begin{array}{l}\text { Establish a logical } \\
\text { navigation order }\end{array}$ & Group form fields \\
\cline { 2 - 3 } & $\begin{array}{l}\text { Do not automatically } \\
\text { cause change in context }\end{array}$ & $\begin{array}{l}\text { Security strategies rather } \\
\text { than captcha }\end{array}$ \\
\hline
\end{tabular}

Besides the e-MAG, federal government has been investing in others artifacts to provide digital accessibility. In 2016, they launched a booklet of good practices for digital accessibility and launched the VLibras Suite, a set of open source computational tools that aim to reduce communication barriers and promote deaf people access to content on computers, mobile devices and web platforms in their natural language of communication [13][14].

\subsection{Accessibility Evaluators}

DaSilva was the first Brazilian evaluator adapted to e-MAG and the first in Portuguese language [4]. Recently, the Brazilian federal government recommended the usage of AccessMonitor and ASESWEB [7][13]. The Site Accessibility Appraiser and Simulator (ASES or ASESWEB) is a Brazilian federal government initiative first launched in 2007 and reissued in 2016. It is completely focused on e-MAG guidelines implementation and gives evidence of errors occurrences considering each one of the six sections of the model [8][13].

\section{WEB PORTALS EVALUATION}

We selected the main web portal of 28 federal agencies with ministry status (22 ministries, 2 secretaries and 4 agencies equivalent to ministries) as the object of our study since they are the most important agencies of the federal government that concentrated important subjects such as health, security, education, agriculture and transport, for example. The two secretaries with ministry status are: Secretary of Government of the Presidency of the Republic (SeGov, in Portuguese) and General Secretariat (SG, in Portuguese). The four agencies with ministry status are: Advocacy-General of the Union (AGU, in Portuguese), Central Bank of Brazil (BC, in Portuguese), Civil House of the Presidency of the Republic (CC, in Portuguese) and Institutional Security Office (GSI, in Portuguese) [17].

We framed our investigation around five research questions:

- $\quad$ RQ1: How many portals use the IDG?

- RQ2: What technologies were used for implementing and maintaining the web portals?

- $\quad$ RQ3: What is the level of compliance of the web portals with the e-MAG standard?

- RQ4: What are the main problems found in the web portals concerning e-MAG recommendations?

- RQ5: How many portals publish the Accessibility Circumstantial Report? 


\subsection{Digital Government Identity and web technologies}

Our first analysis focused on the usage of Digital Government Identity (IDG, in Portuguese). Figure 2 shows the results of a manual analysis conducted over the visual interface of the analyzed web portals to answer RQ1. Only $3(10.7 \%)$ of them are not following the IDG, even though it is mandatory since 2014.

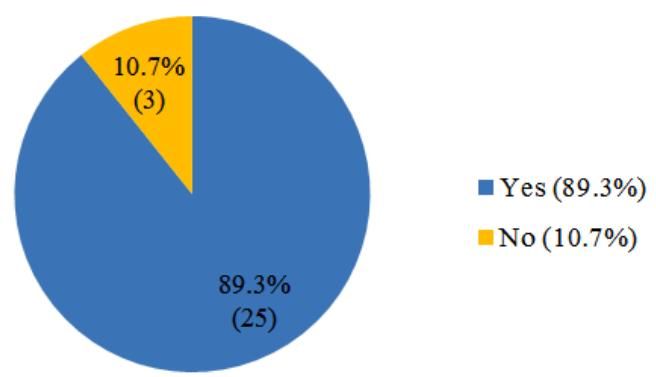

Figure 2. Usage of Digital Government Identity.

In a manual and automatic evaluation to answer RQ2, we discovered which Content Management System (CMS), framework or languages are being used for the development of these web portals. The Brazilian Electronic Government recommends using CMS tools, such as Drupal, Joomla, Plone and Wordpress, for example, to comply with the web standards defined by W3C. In the initial disclosure of IDG, the government mostly uses CMS Plone. However, each institution may choose its own CMS technology used to develop and maintain the web portals [8].

Figure 3 presents the results of the analysis of the source code of the main web portal page. The automatic analysis was performed by W3Techs [28]. Notices that most web portals $(78.6 \%)$ are using CMS Joomla and CMS Plone, each one with $39.3 \%$ of usage, followed by $14.2 \%$ that are using CMS Liferay. Only one web portal was built in ASP language and another one was built with Php. The choice of technology seems not to be relevant, but it may have a strong influence on digital accessibility.

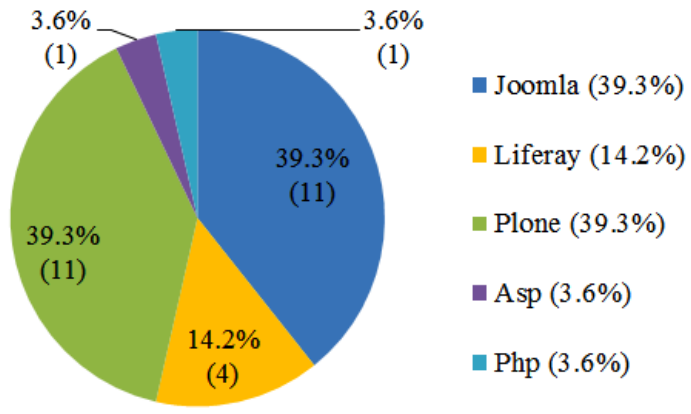

Figure 3. Usage of technologies in e-gov web portals.

All these CMS tools (Joomla, Plone and Liferay) have the Digital Government Identity implemented, which means that they already have basics accessibility functions available, such as anchors to main areas of the page and easy search field in the top of the web portal.

\section{2 e-MAG Recommendations}

Concerning RQ3, compliance with the e-MAG, we use ASESWeb automatic tool to analyze and evaluate accessibility through its coding. One advantage of ASES tool is that it presents the errors already categorized in e-MAG sections [2]. ASESWeb grades the analyzed website according to their compliance with e-MAG: score of $95 \%$ or above represents green signal of good accessibility; more than or equal to $85 \%$ and less than $95 \%$ is yellow; more than or equal to $70 \%$ and less than $85 \%$ is orange; less than $70 \%$ is a red sign, meaning highly compromised accessibility [2].

ASESWEb has an elaborated metrics system to reach these grades. The metrics involve weights for each forty-five recommendations of e-MAG. These weights vary from 1 to 3 , being the most significant weights applying in fundamentals recommendations that can impact on other recommendations. For example, recommendation one, Respecting the W3C Web Standards, of Section Marking, has a greater weight, since it interferes with other recommendations. The number of lines in the source code and the amount of errors occurrence also influence the grade of the web portal [2].

Figure 4 shows the distribution of the web portals analyzed based on their overall score. Only one web portal has more than $95 \%$ of accessibility adherence; most of the web portals (12) has scored between $85 \%$ and $95 \%$; followed by 9 web portals that scored between $70 \%$ and $85 \%$; and there are 6 web portals in a most critical situation with less than $70 \%$ of accessibility adherence.

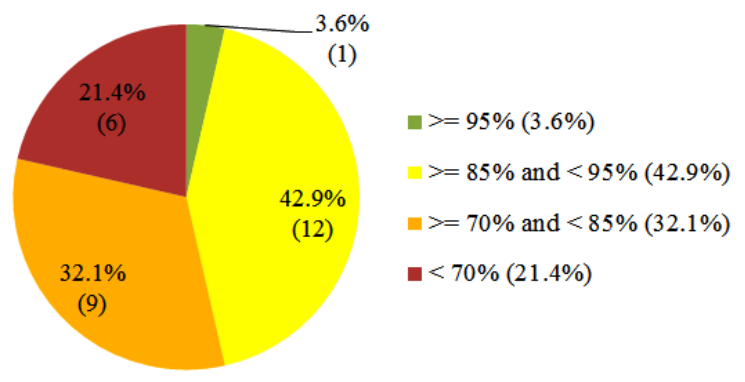

Figure 4. e-MAG adherence according to ASES percentage.

To answer RQ4, we grouped the number of accessibility issues found in each evaluated web portal according to their section in the e-MAG. Figure 5 shows an illustration of the results. Most of the errors are concentrated in two e-MAG sections: Marking, with $87.2 \%$, and Content / Information, with $12.6 \%$. The remaining sections have not presented significant amounts of errors; mainly because the web portals have few elements related to Behavior, Presentation / Design, Multimedia and Forms.

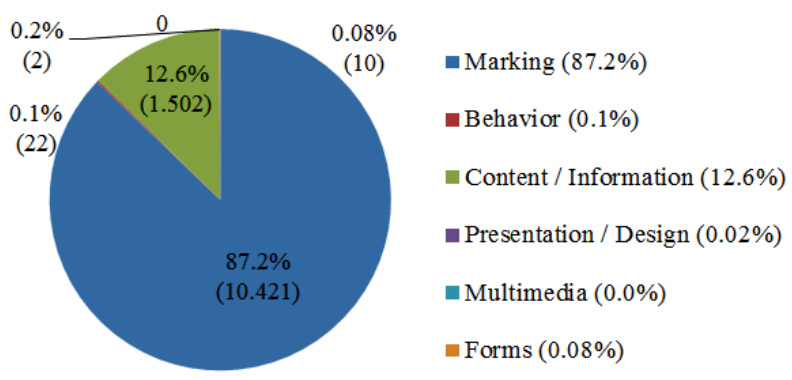

Figure 5. Errors occurrence per e-MAG section. 
We do not discuss here the details of the errors found in the web portals, but we highlight that, in Marking section, one of the most common errors found is the no compliance with HTML Web Standards. In Content / Information section, a common error is the display of non-textual content without an alternative text, which clashes one of the most basic accessibility guideline. For example, every image should have its own HTML "alt" attribute filled with a description, so screen readers would be able to read the description to users who cannot see the screen.

Following, we list the major problems found in the three sections that presented most errors' occurrence:

- Marking: respect the web standards (W3C); provide anchors to go straight to a block; and use header levels correctly.

- Content/Information: describe links clearly and succinctly; provide text alternative for images; and provide an informative title to the page.

- Forms: link labels to your fields; provide text alternatives to form image buttons; and group form fields.

\subsection{Circumstantial Report of Accessibility}

To answer RQ5, we analyzed all web portals to check whether they have the Circumstantial Report of Accessibility published. Figure 6 shows the results. Surprisingly, only 3 out of the 28 analyzed web portals published such a report. Once there is no web portal with $100 \%$ compliance with e-MAG and the deadline to publish such document was January 2nd, 2017, most federal institutions are not following this specific and important legislation to the e-government scenario.

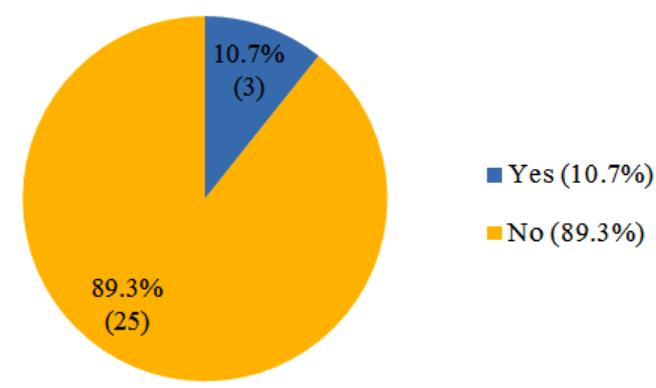

Figure 6. Circumstantial accessibility report availability.

\section{BRAZILIAN ACCESSIBILITY SCENARIO FROM THE PERSPECTIVE OF A BLIND USER}

All legislation and documents that involve accessibility are important, however, it is relevant to understand digital accessibility in the perception of who needs it daily. This study addresses the main challenges and advances in the perception and experience of a blind person. Our interviewee is 34 years old, has been a public servant at a federal university since 2014 , joined the same institution in 2004 as undergraduate student and is currently a $\mathrm{PhD}$ student. She considers herself an experienced user regarding the use of web browsing technologies and has been using screen reader programs for approximately 10 years. These characteristics were determinant for the choice of the interview and the fact that she had a previous working relationship with one of the authors of this paper.

For this research, we conducted a semi-structured interview. It is a process of social interaction, in which the interviewer obtains information from the interviewee through a script elaborated with themes that address, in our case, the central issue about accessibility in government portals. With the support of a script it is possible to guide the questions at the time of the interview [9][11]. The interview was recorded, transcribed literally and then synthesized for this paper. We do not present the script used to guide this interview due to space limitations, but following we summarize the interviewees' response grouped by related topics.

\subsection{First steps towards using assistive technologies and the Internet}

The interviewee's first contact with a screen reader program was in 2003, when she took a course to use a national screen reader, Virtual Vision. Unfortunately, she could not afford a personal computer or assistive technologies such as this screen reader back then. When she had to use the Internet, she relied on a free program developed by the Federal University of Rio de Janeiro (UFRJ), DOSVOX.

In 2008, she bought her first personal computer and started to use the Internet regularly. She had the support of the university's Center for Education, Research, Extension and Attendance in Special Education to set up an email account and related services. She firstly used the Virtual Vision screen reader, then Jaws. Due to the high cost of such technologies, she started using NVDA, a free and open source screen reader.

\subsection{Using government portals and online services}

In her experience, it is difficult to access the content of government web portals. In general, users search for important information, such as legislation or online services available, but they do not provide easy ways for a blind person to navigate. In addition, there is no standardization among web portals.

According to the interviewee, the major problems of the web portals are: absence of the hierarchy on the content; absence of textual descriptions; use of inappropriate terminology, which hinders access even for people without disabilities; menus that do not allow navigation through the screen reader; search engine failure, which can affect any user; inaccessible web forms due to the absence of textual instructions and the proper identification of the input fields the user is filling; captcha resource inaccessible to blind users and lack of interaction in videos.

One of the online services the interviewee tries to use regularly is to issue the electric energy bill, but the company's web portal is not accessible from a blind user perspective: all buttons are images, but no content description is provided. She also has problems to retrieve pay check and financial data on the federal government platform. Moreover, she said blind people cannot file the annual income tax return because the government provides a totally inaccessible program. Like any citizen, she would like to have the autonomy to make it by her own.

Blind people have serious problems with publishers as well. One might think that it has nothing to do with government portals, but many publishers provide products for public libraries and their books are not accessible. When an accessible version of the book is requested, the publisher hires a non-governmental organization 
to produce the content. However, it is a very time-consuming and bureaucratic process, which causes some users, who needs the accessible content, to give up of the request.

As an academic community member, the interviewee mentioned, among others, some of the most used environments: Student Web Portal, in which, despite navigational difficulties, she can see her grades and faults; The Lattes Platform, which became a little more accessible after its reformulation. However, The Carlos Chagas Platform, widely used by academics, is still inaccessible to blind people. She also mentioned some web sites related to Ministry of Education (MEC, in Portuguese) that are not accessible.

The interviewee mentioned only one web portal when asked about web portals with good accessibility: The School of Public Administration (ENAP, in Portuguese). This web portal is easy to navigate with a screen reader program. The ENAP offers free online courses using the Moodle platform. The interviewee has participated in some courses and even with some minor issues, she can navigate, download files and interact with videos.

\subsection{Overcoming the lack of accessibility}

When she cannot access an online service or even fill out a web form or $\log$ in to a system, she tries to contact the institution via email or phone. However, the institution does not always respond cordially and does not provide a solution to the problem. It is very common to receive a standard negative response. Sometimes, the only way to access online services is to rely on family members or colleagues' aid.

\subsection{Evaluating accessibility evolution in the past 10 years}

The interviewee finds that digital accessibility has indeed improved in the last years. There are more generals concerned with accessibility requirements nowadays, and assistive technologies have become more popular and affordable. Governments have been addressing accessibility by means of laws, decrees and mandatory standards.

However, she thinks the Brazilian accessibility model, e-MAG, is getting more and more simplistic since only basic examples of accessibility are used and there is no deepening of how to improve accessibility in complex examples. It should have standardization nearest to the universal standards stipulated by the International Web Content Accessibility Guidelines (WCAG). One advantage of WCAG is that it works with three accessibility levels and it is possible to go deep into each level of knowledge.

Unfortunately, although the usage of the e-MAG is mandatory, there is no effective supervision or even punishment for the institutions and officials. Therefore, it is still not possible yet to have full access to several online services at the governmental level. Likewise, many private and public institutions have raised the flag of accessibility, but their digital content and services are still far below the ideal with respect to accessibility.

Digital accessibility for person with disabilities is a complex issue since there are many disabilities to be considered. For example, sometimes a web portal can be fully accessible for people with low vision, but this same portal maybe cannot be accessible by blind person, elderly or even quadriplegic people.

\subsection{Key aspects to improve accessibility}

Based on her experience, the interviewee highlight some key aspects of digital accessibility she finds researchers and developers should consider: shortcut navigation links, hierarchy of HTML headers, navigation links and buttons, and attention to web forms.

The web portals should offer universal shortcut keys to lead the user directly to the main content area, menu area, search field and web portal footer. The hierarchy headers of HTML language tags h1 through h6 - must be respected. This is the main mistake that the interviewee finds in web portals. The correct use of headers makes it easier to navigate using screen readers since they use the hierarchy headers to prioritize navigational elements. Links and buttons are very important in navigation so they must be correctly implemented. It is also necessary to name and identify all the links textually. Buttons should use their own tags and not images with links. In web forms, input fields must be labeled so the user can know what type of input is required. If captcha feature is available, it must be fully accessible. Features such as high contrast are also important for people with low vision.

The interviewee also mention that, once the current trend is to make all documents available in digital format, which is already a reality in courts of justice, government agencies and even universities, for instance, they must be accessible by anyone, even disabled people.

\section{DISCUSSION}

Since the beginning of the Brazilian e-government, the federal government has demonstrated a real concern on providing citizens with accessible information and online services. It has been almost 17 years since the first law regarding digital accessibility in the federal government context was published, and almost 10 years of the e-MAG publication. Since then, several legislation, documents and supporting tools for improving the accessibility of digital platforms have emerged.

The federal government strategy for achieving high levels of accessibility is straightforward. Federal agencies are recommended to use CMS to develop and maintain web portals since they follow W3C standards. It is also important to choose a CMS that has more adherence to the accessibility standards and for which IDG themes are available. On top of that, developers need to follow the e-MAG guidelines so that the accessibility goals are achieved. Federal bodies must also assess their digital platforms and publish the Accessibility Circumstantial Report with the work plan to solve remaining issues.

It is surprising, therefore, that federal web portals present so many accessibility problems so that Brazilian citizens with disabilities have the basic right to access public information and online services denied. We noticed that most federal agencies struggle to implement even the most basic recommendations of this standard. Most errors fall in the category of Marking and Content/Information. This information is confirmed for both our quantitative analysis using the ASESWeb evaluator and the report on the personal experience of our interviewee.

In our analysis, we found out that around $75 \%$ of the web portals were developed using a recommended CMS. In 2015, Oliveira and Eler concluded that only $62 \%$ of the 38 federal agencies with ministry status adopted the IDG, which is understandable since 
the IDG was firstly published in 2014 [16]. Now, we noticed a clear improvement in this matter once $90 \%$ of the analyzed web portals implement the IDG theme. However, since the IDG was published three years ago, we expected that all web portals implemented the IDG theme.

Unfortunately, the federal government has not yet conducted any rigid investigation in this matter and has not held any institution accountable for accessibility problems. When it comes to physical accessibility, there are well established laws and procedures. One cannot open a medical practice, for example, if the building does not comply with all construction standards, including physical accessibility. We wonder whether the same procedure should be extended to federal or services providers' web portals. If there were more stringent supervision, an electronic service could only be published after being verified if no citizen had difficulties or limitations in accessing it.

In other countries, people with disability are becoming more aware of their rights and have been filing lawsuits against institutions that fail to provide users with their basic accessibility requirements. Higher education institutions of the USA, for instance, are facing lots of complaints and lawsuits because they fail to provide students with accessible digital platforms. Most complains are spurred by the usage of inaccessible devices in the classroom such as clickers and electronic readers; use of inaccessible websites and mobile apps; use of technologies and materials that are not accessible to screen readers. For example, video captions are essential for deaf and hard of hearing individuals, hence failing to caption educational video discriminates against these individuals, violating federal law. The Accessible Technology Team (ATT) of the Information Technology Systems and Services, University of Minnesota Duluth, maintains a website with a list of several litigations involving accessibility issues in higher education institutions [3].

Based on previous and yet unpublished work, and the TCU report, it seems that the non-compliance with the e-MAG may have two main causes: the lack of a proper IT strategy to deliver egovernment solutions that achieve the expected levels concerning all federal government standards such as accessibility, interoperability, and transparency, for instance; and staff shortage, high demand and tight deadlines faced by the technical teams of most federal agencies [24][29].

Regardless the reasons, the basic rights of any citizen must be assured, not only to access information and online services, but also to engage into activities proposed by a government that intend to promote a more participatory decision-making process. Therefore, the results of this paper is a clear indication that the federal government needs to revisit its strategy to assure that all quality standards are followed.

\section{RELATED WORK}

In this section, we highlight three studies conducted to evaluate accessibility in the Brazilian government context or in developing countries. In 2015, Oliveira and Eler used the daSilva accessibility evaluator to assess the main web portal of 38 federal agencies with ministry status to check whether they follow the W3C standards (XHTML, HTML and CSS), the three priority levels of WCAG, e-MAG, and Digital Government Identity. They found that that the main portals failed by far to implement the standards determined by the Brazilian Electronic Government, and only $62 \%$ adopted the IDG [16].
In the same year, Serra et. al. evaluated four Brazilian egovernment mobile applications using an own WCAG 2.0 adaptation methodology. They discuss the methodological adaptations of the 61 success criteria of WCAG 2.0 for the context of mobile applications for Android and IOS pointing its current limitations. The results showed that many elementary accessibility problems, such as colour contrast and navigationrelated were extensively found in all applications evaluated [22].

In 2016, Agangiba el. al. presented the accessibility research trends in development countries. The authors question how researchers conduct studies on e-government accessibility towards people with disability and what research approach they adopt. The results present findings based on systematic literature review with the purpose of identifying key research focus, methodologies and the theoretical perspectives used [1].

\section{CONCLUDING REMARKS}

This paper presented an investigation of the current scenario of digital accessibility in the context of the Brazilian federal government. We evaluated the main web portals of 28 federal agencies with ministry status and concluded that most of them fails to follow the accessibility laws and standards. Few web portals presented an acceptable level of compliance with e-MAG and published the Accessibility Circumstantial Report to present a work plan on how accessibility issues will be addressed. We also presented an interview with a blind person to highlight the main hurdles to use online platforms that not complies with fully eMAG adherence. This interview emphasized the importance of digital accessibility and standards in the perspective of a person with disability.

As future work, we plan to devise a method to help developers to implement the forty-five recommendations of the e-MAG standard or even a tool that automatically generates the correct implementation of several features considering the e-MAG recommendations.

\section{REFERENCES}

[1] Agangiba, M, and Kabanda, S. 2016. E-Government Accessibility Research Trends in Developing Countries. Mediterranean Conference on Information Systems (MCIS). Paper 8. Available: http://aisel.aisnet.org/mcis2016/8. Accessed on: Nov, 15, 2016.

[2] ASES. 2017. Avaliador e Simulador de Acessibilidade em Sítios. Available: http://asesweb.governoeletronico.gov.br. Accessed on: Fev., 10, 2017.

[3] Carlson, L. L. Higher Ed Accessibility Lawsuits, Complaints, and Settlements. Available:

http://www.d.umn.edu/ lcarlson/atteam/reports/litigation/law suits.html. Accessed on: Feb., 25, 2017.

[4] DaSilva. 2016. O primeiro avaliador de acessibilidade em português. Available: http://www.dasilva.org.br. Accessed on: Dec., 13, 2016.

[5] EGD. 2016. Estratégia de Governança Digital. Available: https://www.governoeletronico.gov.br/egd/documentos. Accessed on: Dec, 28, 2016.

[6] E-MAG. 2017. Modelo de Acessibilidade em Governo Eletrônico - E-MAG. Available: http://emag.governoeletronico.gov.br. Accessed on: Jan., 20, 2017. 
[7] FAD. 2017. Relatório Circunstanciado de Acessibilidade. Available: http://fad.governoeletronico.gov.br. Accessed on: Feb., 10, 2017.

[8] GovBR. 2017. Programa de Governo Eletrônico Brasileiro. Available: http://www.governoeletronico.gov.br. Accessed on: Jan., 20, 2017.

[9] Haguette, T. M. F. 1995. Metodologias Qualitativas na Sociologia. Petrópolis: Vozes, 1995.

[10] IBGE. 2016. Vamos conhecer o Brasil: características da população. Available: http://7a12.ibge.gov.br/vamosconhecer-o-brasil/nosso-povo/caracteristicas-dapopulacao.html. Accessed on: Dec., 15, 2016.

[11] Lakatos, E. M. and Marconi, M. A. 2001. Fundamentos de Metodologia Científica. São Paulo: Ed. Atlas, 2001.

[12] Marzullo, F. P. 2009. SOA na prática: inovando seu negócio por meio de soluções orientadas a serviços. São Paulo: Novatec Editora, 2009.

[13] Ministério do Planejamento. 2016. Governo lança ferramentas para promover a acessibilidade digital. Available: http://www.planejamento.gov.br/noticias/planejamentolanca-ferramenta-de-acessibilidade-digital-1. Accessed on: Feb., 10, 2017.

[14] Ministério do Planejamento. 2016. Suíte VLibras está entre as 100+ inovadoras no uso de TI. Available: http://www.planejamento.gov.br/noticias/suite-vlibras-estaentre-201 cas-100-inovadoras-no-uso-de-ti201d. Accessed on: Feb., 10, 2017.

[15] Musafir, V. E. N. and Freitas, C. S. 2015. Brazilian eGovernment Strategies. Proceedings of the 15th European Conference on e-Government. University of Portsmouth, UK. pp. 197-197.

[16] Oliveira, A. D. A. and Eler, M. M. 2015. Accessibility in Electronic Government: a study on the implementation of web standards in sites gov.br. Proceedings of the Annual Conference on Brazilian Symposium on Information System, Goiania, Goias, Brazil. pp. 691-698.

[17] Palácio do Planalto. 2017. Ministros. Available: http://www2.planalto.gov.br/presidencia/ministros. Accessed on: Dec, 7, 2016.

[18] Pimenta, M. S. and Canabarro, D. R. 2014. Governança Digital. UFRGS. Available: https:/www.ufrgs.br/cegov/files/livros/gtdigital.pdf Accessed on: Dec, 28, 2016.
[19] Portal Brasil. 2013. Presidenta Dilma apresenta o novo Portal Brasil.Available: http://www.brasil.gov.br/governo/2013/09/dilma-anunciareformulacao-do-portal-brasil. Accessed on: Mar., 3, 2016.

[20] Portal Brasil. 2017. Governo Digital. Available: http://www.brasil.gov.br/governo-digital. Accessed on: Jan., $20,2017$.

[21] SDH. 2010. Cartilha do Censo 2010 - Pessoas com Deficiência. Available:

http://www.pessoacomdeficiencia.gov.br/app/sites/default/fil es/publicacoes/cartilha-censo-2010-pessoas-comdeficienciareduzido.pdf. Accessed on: Dec, 7, 2016.

[22] Serra, L. C. and Carvalho, L. P. and Ferreira, L. P. and Vaz, J. B. S. and Freire, A. P. 2015. Accessibility Evaluation of EGovernment Mobile Applications in Brazil. Procedia Computer Science 67 (2015) 348 - 357. 6th International Conference on Software Development and Technologies for Enhancing Accessibility and Fighting Infoexclusion (DSAI). DOI= http://dx.doi.org/10.1016/j.procs.2015.09.279.

[23] TCU. 2014. Tribunal de Contas da União - Levantamento de governança de tecnologia da informação. Available: http://portal.tcu.gov.br/comunidades/fiscalizacao-detecnologia-da-informacao/atuacao/perfil-de-governanca-deti. Accessed on: Jan., 20, 2017.

[24] TCU. 2015. Tribunal de Contas da União - levantamento do pessoal de tecnologia da informação. Available: https://portal.tcu.gov.br/biblioteca-digital/levantamento-naarea-de-pessoal-de-ti-da-administracao-publica-federal.htm. Accessed on: Jan., 20, 2017.

[25] United Nations. 2014. e-Government for the future we want. New York: UN, 2014. Available: http://unpan3.un.org/egovkb/Portals/egovkb/Documents/un/2 014-Survey/E-Gov_Complete_Survey-2014.pdf. Accessed on: Dec, 7, 2016.

[26] United Nations. 2016. e-Government in support of sustainable development. New York: UN, 2016. Available: https://publicadministration.un.org/egovkb/enus/Reports/UN-E-Government-Survey-2016. Accessed on: Nov., 3, 2016.

[27] W3C. 2016. World Wide Web Consortium. Available: http://www.w3c.org. Accessed on: Dec., 20, 2016.

[28] W3Techs. 2017. Web Technology Surveys. Available: https://w3techs.com/sites. Accessed on: Feb., 10, 2017. 